\title{
Class Action terhadap Perusahaan Pers menurut Undang-undang Perlindungan Konsumen
}

\author{
$\frac{\text { Hasan }}{\text { hasan2000@yahoo.co.id }}$
$\begin{aligned} & \text { FSH-VIN Sunan Ampel } \\ & \text { If. A. Yani 117 Surabaya, Indonesia }\end{aligned}$
}

Abstract: The Indonesian economy is growing very rapidly. It is depicted by the emergence of numerous industries, including the print and electronic media industry or the press. At the same time, the reform period has given "freedom of the press" to its position. However, it is common for the press industry to inflict harm to the consumers. Subsequently, a legal remedy in the form of class action comes to be known. In this context, this paper is presented, which aims to find out the opinion of Islamic criminal law regarding class action against press companies according to Law Number 8 of 1999 concerning Consumer Protection. The results of the study concluded that the cause of occurrence of a class action against the press company is due to the failure which causes mass damages, including negligence of the rule of law (iqnorantia Juris), negligence of the function (iqnorantia function), negligence of information (iqnorantia infom), negligent of national philosophy (iqnorantia nation), and others. Class action against press companies occurs because of the disobedience of the laws and regulations in force.

Key Word: Class action, Crime against press, Protection of consummer, Islamic Criminal Law

\begin{abstract}
Abstrak: Dewasa ini perekonomian bangsa Indonesia berkembang sangat pesat, terlihat dengan bermunculan berbagai industri, di antaranya adalah industri media cetak dan elektronik atau pers. Di sisi lain masa reformasi telah memberikan "kebebasan pers" pada posisinya. Namun, di sisi lain, tak jarang kebebasan pers ini justru merugikan pihak konsumen, sehingga sebagai upaya hukum dikenal "class action". Dalam konteks inilah tulisan ini hadir, yaitu bertujuan mengetahui tinjauan hukum pidana Islam tentang class action terhadap perusahaan pers menurut Undangundang Nomor 8 Tahun 1999 tentang Perlindungan Konsumen. Hasil penelitian menyimpulkan bahwa dalam yang melatar belakangi terjadinya class action terhadap perusahaan pers adalah karena adanya pengabaian yang
\end{abstract}


menyebabkan kerugian yang bersifat massal, di antaranya pengabaian kaidah hukum (iqnorantia juris), pengabaian fungsi (iqnorantia function), pengabaian keseimbangan informasi (iqnorantia infom), pengabaian wawasan kebangsaan (iqnorantia nation), dan lainnya. Class action terhadap perusahaan pers terjadi dikarenakan perusahaan pers bertindak tidak sesuai dengan peraturan perundangundangan pers yang berlaku.

Kata kunci: Class action, tindak pidana pers, hukum perlindungan konsumen, hukum pidana Islam

\section{Pendahuluan}

Dewasa ini perekonomian bangsa Indonesia berkembang sangat pesat, terutama perkembangan produksi barang dan jasa. Hal ini dapat kita lihat dengan bermunculannya berbagai industri, khususnya industri media cetak dan elektronik. Bergantinya pemerintahan Soeharto atau yang lebih di kenal dengan Rezim Orde Baru. Dengan orde reformasi, membawa dampak positif bagi insan pres, "Kebebasan Pers" 1 yang telah dirampas atau dikekang selama masa pemerintahan Soeharto telah diperoleh kembali. Terbukti dengan bermunculannya industri-industri media cetak dan elektronik. Hal ini terjadi karena mudahnya pengurusan SIUPP (surat izin usaha penerbitan pers). Arti SIUPP sendiri menurut Oemar Sena Adji merupakan "Faktor ekonomis yang tidak boleh berhubungan dengan kebebasan untuk mengatakan pendapat atau pikiran melalui pers."

Setelah tumbangnya masa pemerintahan Soeharto dan digantikan oleh Bj. Habibie, kemudian digantikan oleh pemerintahan presiden Abdurahman Wahid maka kebebasan pers makin eksis. ${ }^{2}$ Hal ini terbukti dengan dihapuskannya

${ }^{1}$ Kebebasan pers di sini merupakan terjemahan dari freedom of the press, yang dianalogikan sebagai kebebasan dari penguasa. Lihat: Acan Mahdi, "Kebebasan Pers dan Hak Publik," Al-Hikmah 8, no. 1 (2014): 20.

${ }^{2} \mathrm{Hal}$ ini tak lepas bahwa kebebasan pers, dalam perspektif hukum positif, merupakan salah satu wujud kedaulatan rakyat dan menjadi unsur yang sangat penting untuk menciptakan kehidupan bermasyarakat, berbangsa dan bernegara yang berasaskan prinsip-prinsip demokrasi, keadilan, dan supremasi hukum. LIhat Idri, "Pers dalam Wacana Hukum (Kajian tentang Kebebasan, Tanggungjawab, dan Deviasi Pers dalam Perspektif Hukum Islam dan Hukum Positif di Indonesia)," Al-Ihkam V, no. 2 (Desember 2010): 233. 
Departemen Penerangan, pencabutan aturan SIUPP, legalitas profesi wartawan non persatuan wartawan Indonesia (seperti halnya Aliansi Jurnalistik Independen). Hal tersebut menopang bermunculannya industri pers baru, baik dalam bentuk media cetak maupun elektronik.

Dengan semakin menjamurnya industri pers, maka masyarakat semakin mempunyai banyak pilihan untuk mendapatkan informasi baik informasi yang berhubungan dengan ekonomi, politik, sosial, budaya, maupun hiburan.

Pada era reformasi ini, media cetak dan elektronik tidak hanya mengelola berita, akan tetapi juga aspek-aspek yang lain. oleh karena itu, fungsi dari media pers bukan hanya untuk menyiarkan informasi saja akan tetapi mempunyai fungsi-fungsi sebagai berikut: ${ }^{3}$

1. Fungsi menyiarkan informasi. ${ }^{4}$

2. Fungsi mendidik. ${ }^{5}$

3. Fungsi menghibur. ${ }^{6}$

4. Fungsi mempengaruhi. ${ }^{7}$

Adanya fungsi-fungsi yang terkandung di dalam teks media, khususnya untuk fungsi mempengaruhi (poin 4) hal tersebut membuktikan bahwasannya media memiliki peran yang sangat penting dalam memajukan suatu negara. Media, jika diberikan "kebebasan", di satu sisi bisa mendatangkan nilai positif di mana pers dapat menjalankan fungsi kontrol dan penyebarluasan berita, namun tidak jarang di sisi lain

3 Onong Uchjana Effendy, Ilmu, Teori dan Filsafat Komunikasi (Bandung: Citra Aditya Bakti, 2003), 93-94.

4 Menyiarkan informasi adalah fungsi utama dari media pers. Karena khalayak memerlukan informasi mengenai kejadian yang terjadi di muka bumi ini.

5 Media sebagai sarana mendidik yaitu pendidikan massa (mass education), surat kabar memuat tulisan-tulisan yang mengandung pengetahuan, sehingga khalayak pembaca bertambah pengetahuannya.

${ }^{6}$ Fungsi ini adalah untuk mengimbangi berita-berita yang berat (hard news) dan artikel-artikel yang berbobot.

7 Mempengaruhi adalah fungsi yang menyebabkan media memegang peranan yang penting dalam kehidupan masyarakat. 
mempunyai dampak negatif (negative spread), misalnya terjadinya eksploitasi dan manipulasi data dan berita. ${ }^{8}$

Dalam kebebasannya untuk mengakses informasi membuat pers menjadi salah satu kebutuhan manusia yang esensial untuk berbagai tujuan. Dalam hal ini pers, sebagai media produk yang memiliki sifat universal dan aktual dituntut untuk menyediakan berbagai informasi serta sebagai penyambung aspirasi rakyat. Hal tersebut menunjukkan betapa besar kekuatan pers.

Bahkan di dalam trias politika, pers menduduki elemen keempat dalam sebuah negara atau yang lebih dikenal dengan istilah the fourth element for government. ${ }^{9}$ Pers dalam konteks ini berfungsi sebagai "anjing penggonggong", selain fungsi ekonomi, informasi, hiburan dan pendidikan bagi masyarakat.10

Kebebasan pers memang suatu bukti wujud dari kedaulatan rakyat yang memiliki peranan yang sangat penting dalam era reformasi. ${ }^{11}$ Memang harus diakui bahwasannya pers terkadang menyalah-gunakan kebebasannya sendiri (abuse of liberty). Hal tersebut dapat menimbulkan polemik baru dan juga dapat menimbulkan asumsi negatif terhadap media itu sendiri. Industri media cetak dan elektronik pada masa sekarang ini, lebih mengutamakan segi sensasi dangkal dan lebih mengutamakan kepentingan komersial atau mencari laba sebesar-besarnya semata, dibandingkan bobot dari suatu

8 Idri, "Pers dalam Wacana Hukum (Kajian tentang Kebebasan, Tanggungjawab, dan Deviasi Pers dalam Perspektif Hukum Islam dan Hukum Positif di Indonesia)," 225.

${ }^{9}$ Lebih jauh tentang hal ini lihat: Moh Mahfud MD, Hukum dan Pilar-pilar Demokrasi (Yogyakarta: Gama Media, 1999), 367.

10 Mahdi, "Kebebasan Pers dan Hak Publik," 24.

11 Hampir di seluruh negara, kebebasan pers dipandang sebagai hal yang amat urgen karena kebebasan itu terkait dengan kemerdekaan mengeluarkan pikiran dan pendapat, hak mempertahankan dan memperoleh jaminan konstitusional. Lihat: Idri, "Pers dalam Wacana Hukum (Kajian tentang Kebebasan, Tanggungjawab, dan Deviasi Pers dalam Perspektif Hukum Islam dan Hukum Positif di Indonesia)," 223. 
berita atau wacana yang disajikan.12 Sehingga disadari atau tidak terjadi pelanggaran-pelanggaran.

Hal ini bisa jadi karena semakin banyaknya industriindustri media cetak dan elektronik, sehingga menyebabkan semakin ketatnya persaingan bisnis untuk mendapatkan market/pasar. Agar supaya tetap eksis dalam bisnis tersebut tak jarang industri media cetak dan elektronik menggunakan berita atau gambar erotik sebagai daya tarik media tersebut. Karena disadari atau tidak obyek-obyek yang dapat dikembangkan secara komersial adalah berkisar antara harta, tahta dan wanita. ${ }^{13}$

Pelanggaran-pelanggaran yang telah dilakukan oleh industri media cetak dan elektronik itu bisa terjadi karena adanya salah penafsiran tentang kebebasan pers itu sendiri. Padahal kebebasan pers itu sendiri telah dirumuskan dalam ketentuan pasal 4 ayat (2) dan (3) Undang-undang Pers nomor 40 tahun 1999 beserta penjelasannya, yang intinya "Pers bebas dari pencegahan penyelenggaraan dan atau penekanan dalam upaya mencari, memperoleh dan menyebarkan gagasan informasi”. ${ }^{14}$

Dengan demikian tidak menutup kemungkinan terjadinya suatu pelanggaran yang dilakukan oleh perusahaan pers yang mengakibatkan kerugian yang bersifat massal. Hal ini dapat terjadi karena adanya salah penafsiran tentang kebebasan pers dan semakin ketatntya persaingan dalam bisnis tersebut. Maka dengan demikian perlu adanya aturan yang mengatur tentang class action.

Tentang adanya kemungkinan class action ini dikarenakan adanya kerugian yang diderita oleh konsumen yang berjumlah banyak (sekelompok Konsumen) untuk

12 Idri, 225.

13 Burhan Bungin, Erotika Media Massa (Surakarta: Universitas Muhamadiyah Surakarta, 2001), 2.

${ }_{14}$ Di dalam Undang-undang ini tidak terdapat keharusan memiliki SIT dan SIUPP dari pemerintah sebagaimana dijumpai pada kedua Undang-undang pers terdahulu. Dengan demikian lebih menjamin adanya kebebasan pers dan perkembangan media cetak di Indonesia, karena tidak ada pembreidelan dan sensor. Lihat: Asnawi Murani, "Aspek Hukum dan Tanggung Jawab Pers," Jurnal Ilmu Komunikasi 1, no. 2 (Desember 2015): 36. 
memungkinkan diajukannya suatu gugatan/tuntutan. Ini sebagaimana ditentukan di dalam pasal 46 ayat (1) huruf (B) UUPK, yang menyatakan bahwa "Gugatan atas pelanggaran pelaku usaha dapat dilakukan oleh sekelompok konsumen yang mempunyai kepentingan yang sama".15

Akan tetapi yang perlu diperhatikan bahwa class action dalam Hukum Perlindungan Konsumen adalah berbeda dengan calss action yang lainnya. ${ }^{16}$

Di dalam Islam memandang kehidupan sebagai satu kesatuan dan tidak dapat dipilih-pilih. Serta memandang kehidupan seseorang sebagai bagian yang tidak terpisahkan dari kehidupan masyarakat. Masing-masing individu saling melengkapi dalam tatanan social. Inilah yang dalam Islam disebut konsep falah, yaitu terwujudnya kebahagiaan dengan cara menciptakan keharmonisan antara kebutuhan moral dan material dan aktualisasi keadilan sosio-ekonomi serta persaudaraan dalam masyarakat manusia. ${ }^{17}$

Agama Islam yang dibawa Rasulullah saw mempunyai keunikan tersendiri. Bukan hanya bersifat comprehensive tetapi juga bersifat universal. Comprehensive berarti mencakup seluruh aspek kehidupan baik ritual (ibadah) maupun sosial (muamalah). Universal bermakna dapat diterapkan dalam setiap waktu dan tempat, sampai akhir zaman. Keuniversalan ini, akan tampak jelas terutama dalam bidang muamalah. Bidang tersebut bukan saja luas dan fleksibel, bahkan tidak memberikan special treatment bagi muslim dan membedakan dari non-muslim. ${ }^{18}$

15 Bambang Sugeng A.S, "Penyelesaian Sengketa Konsumen Melalui Gugatan Kelompok," Yuridika 25, no. 2 (Mei-Agustus 2010): 118.

16 Kadir Mappong, "Prosedur Gugatan Perwakilan (Class Action) dan Kaitannya dengan Hukum Acara Perdata" (Seminar Sehari, Oktober 2002), 3.

17 Atok Syihabuddin, "Etika Distribusi dalam Ekonomi Islam," Jurnal AlQ⿳亠二⿵冂⿱八口⿰ 20, no. 1 (Juni 2017): 85.

18 Dengan redaksi lain, Muhammad Yazid, menyatakan bahwa Islam sebagai al-din mengandung ajaran yang komprehensif dan sempurna (shumūl). Islam mengatur seluruh aspek kehidupan manusia. Tidak saja aspek ibadah, tetapi juga aspek muamalah. Lihat: Muhammad Yazid, "Prospek Ekonomi Syariah dalam Menjawab Tantangan Keadilan Sosial dan Kapitalisme Global," Jurnal AlQänün 12, no. 1 (Juni 2009): 195. 
Tulisan ini hadir dengan latar belakang sebagaimana tersebut di atas, dan bertujuan mengetahui: (1) hal-hal yang melatar belakangi terjadinya class action terhadap perusahaan pers, dan (2) kreteria pelanggaran perusahaan pers dalam konteks Indonesia, serta (3) tinjauan hukum pidana Islam tentang class action terhadap perusahaan pers menurut Undang-undang Nomor 8 tahun 1999 tentang Perlindungan Konsumen.

\section{Class Action Terhadap Perusahaan Pers Pengertian dan tujuan class action}

Istilah class action di Indonesia merupakan suatu hal yang baru. Istilah class action ini berasal dari. Bahasa Inggris, yaitu gabungan kata class dan action. Perngertian class adalah sekumpulan orang, benda, kualitas atau kegiatan yang mempunyai kesamaan sifat atau ciri. Sedangkan pengertian action dalam dunia hukum adalah tuntutan yang diajukan ke pengadiian. Dengan demikian class action menggambarkan suatu pengertian di mana sekelompok besar orang berkepentingan dalam suatu perkara, satu atau lebih dapat menuntut atau dituntut mewakili kelompok besar orang tersebut tanpa harus menyebutkan satu persatu anggota kelompok yang diwakili. ${ }^{19}$

Dan perlu diketahui bahwa class action yang telah dijelaskan pengertiannya di atas, berbeda dengan gugatan kelompok, dalam konteks Hukum Perlindungan Konsumen. ${ }^{20}$ Di dalam gugatan kelompok yang bergerak adalah LSM yang bergerak di bidang lingkungan hidup yang berhak mengajukan gugatan yang mana mempunyai maksud dan tujuan untuk melindungi lingkungan hidup. Dan juga perlu diketahui bahwa di dalam gugatan kelompok bukan

19 Bambang Sutiyoso, "Implementasi Gugatan Legal Standing dan Class Action dalam Praktik Peradilan di Indonesia," Jurnal Hukum 26, no. 11 (Mei 2004): 65.

20 Sugeng A.S, "Penyelesaian Sengketa Konsumen Melalui Gugatan Kelompok," 119. 
menuntut ganti rugi untuk masyarakat, tetapi hanya menuntut pemulihan lingkungan hidup saja. ${ }^{21}$

Dalam kehidupan sosial, hak asasi manusia dan hak moral merupakan hak yang harus dijamin oleh sistem hukum, yang meliputi hak-hak atas kehidupan, kebebasan, keadilan dan kesamaan. Sering kali hak-hak tersebut tidak terpisahkan antara satu dengan lainnya, tetapi saling berhubungan. Jadi apabila terdapat suatu perbuatan melanggar hukum yang menimbulkan kerugian secara massal, baik dilakukan oleh perusahaan Negara maupun perusahaan swasta, maka harus tetap menerima ganjaran dari perbuatan yang telah dilakukannya sesuai dengan undang-undang yang berlaku.

Di dalam kehidupan sosial masyarakat secara tidak langsung selalu dihadapkan dengan perbuatan melanggar hukum atau kriminal. ${ }^{22}$ Di mana kejahatan memiliki ciri khas sesuai dengan tempat masyarakat yang bersangkutan. Kriminal (kejahatan) merupakan jenis atau perbuatan yang memiliki ciri-ciri, sebagai berikut:

1. Tindakan tersebut melanggar hukum.

2. Yang dirasakan merugikan dan menjengkelkan, oleh masyarakat dimana perilaku itu dilakukan.

3. Yang terhadapnya masyarakat berusaha mencegah dan mengambil tindakan terhadap apa yang telah dilakukan.

Ketiga poin dari penjelasan tentang perbuatan melanggar hukum di atas. Dengan demikian class action sangatlah relevant diterapkan di dalam kehidupan masyarakat. Ini bertujuan untuk menindak lanjuti kasus yang mengakibatkan kerugian yang bersifat massal. Hal tersebut dapat terjadi seiring dengan perkembangan zaman.

Prosedur yang terdapat di dalam class action sesuai dengan asas yang terdapat di dalam peradilan, yaitu sederhana, cepat, dan biaya ringan. Hal ini sesuai dengan penjelasan yang terdapat di dalam pasal 4 UU No 14 Tahun

21 Mappong, "Prosedur Gugatan Perwakilan (Class Action) dan Kaitannya dengan Hukum Acara Perdata," 3.

22 Nafi' Mubarok, Kriminologi dalam Prespektif Islam (Sidoarjo: Dwiputra Pustaka Jaya, 2017), 1. 
1970.23 Adapun tujuan dari class action itu sendiri sama dengan Negara-negara lain pada umumnya diantaranya:

1. Proses perkara menjadi sangat ekonomis (judicial economy).

2. Akses terhadap peradilan (access to justice)

3. Perubahan sikap pelaku pelanggaran (behaviour modifaction)

4. Proses perkara menjadi sangat ekonomis (judicial economy). ${ }^{24}$

Dengan mengunakan class action dalam berperkara berarti mencegah pengulangan (repetition) gugatan. Sedangkan dalam gugatan secara individual tidak ekonomis bagi pengadilan apabila harus melayani gugatan-gugatan sejenis secara individual. ${ }^{25}$

Bukan rahasia awam lagi bahwasanya berperkara di pengadilan menelan biaya yang tidak sedikit dibandingkan dengan besarnya ganti kerugian yang diberikan. Hal ini menjadi polemik bahwasanya apabila pihak korban termasuk golongan kesulitan masalah ekonomi maka secara otomatis akan merasa sulit untuk mendapatkan keadilan. Akan tetapi dengan adanya class action menjadi salah satu fasilitas untuk mencari kadilan bagi para korban, karena biaya perkara dan menyewa pengacara menjadi jauh lebih murah, dibandingkan dengan gugatan secara individu. Hal ini sesuai dengan butir yang terdapat didalam UUD 1945 pasal 28D ayat 1 yang berbunyi bahwa "setiap orang berhak atas pengakuan, jaminan, perlindungan dan kepastian hukum yang adil serta perlakuan yang sama dihadapan hukum". 26

Dengan demikian proses perkara menjadi sangat ekonomis tidak saja dirasakan oleh pihak pengugat namun juga dirasakan oleh pihak tergugat. Hal ini dikarenakan pengajuan perkara secara class action membuat pihak

${ }^{23}$ Ahmad Santoso, Konsep dan Penerapan Gugatan Perwakilan Class Action (Jakarta: ICEL, 1997), 12.

${ }^{24}$ Emerson Yuntho, Class Action: Sebuah Pengantar (Jakarta: ELSAM, 2007), 2.

25 Santoso, Konsep dan Penerapan Gugatan Perwakilan Class Action, 12.

26 Undang-undang Dasar Tahun 1945 (yang sudah diamandemen). 
tergugat hanya cukup satu kali mengeluarkan biaya untuk melayani gugatan dari pihak-pihak yang merasa dirugikan. ${ }^{27}$

Kelebihan-kelebihan class action, adalah sebagai berikut:

1. Akses terhadap keadilan

Pengajuan gugatan secara individu akan mengakibatkan beban bagi calon pengugat. Sering sekali beban tersebut menjadi salah satu hambatan bagi seseorang dalam memperjuangkan haknya dipengadilan. Maka melalui class action ini, kendala yang bersifat ekonomis dapat teratasi dengan cara para korban mengabungkan diri bersama class member dalam satu gugatan meskipun pemahaman tentang hukum lemah.

2. Perubahan sikap pelanggaran (behaviour modifaction)

Dengan mengunakan akses class action secara otomatis berpeluang untuk mendorong perubahan sikap dari siapa saja yang berpotensi untuk merugikan kepentingan masyarakat, baik yang akan melakukan atau sudah melakukan suatu perbuatan melawan hukum. Dengan kata lain untuk mendorong pihak swasta maupun pemerintahan untuk bertindak ekstra hati-hati dalam menjalankan segala usahanya dan juga memberikan sikap jerah bagi mereka yang berpotensi untuk melakukan perbutan tersebut.28

\section{Dasar Hukum Class Action}

Class action merupakan suatu hal yang baru, khususnya di Indonesia. Class action belum diatur dalam hukum perdata, akan tetapi yang menjadi dasar hukum adalah:

1. Undang-undang No. 23 Tahun 1997 tentang Penggelolaan Lingkungan Hidup.

2. Undang-undang Nomor 41 Tahun 1999 tentang Kehutanan.

27 Sutiyoso, "Implementasi Gugatan Legal Standing dan Class Action dalam Praktik Peradilan di Indonesia," 65.

28 Yuntho, Class Action: Sebuah Pengantar, 2. 
3. Undang-undang Nomor 8 Tahun 1999 tentang Perlindungan Konsumen.

\section{Syarat-syarat Class Action}

Dalam peroses perkara yang menggunakan class action, maka perlu diketahui bahwa dalam class action mempunyai syarat-syarat sebagai berikut: 29

1. Adanya sejumlah anggota yang besar (numerosity)

Jumlah anggota kelompok (class members) harus sedemikian banyak sehingga tidak efektif dan efisien apabila gugatan dilakukan secara sendiri-sendiri (individu).

2. Adanya kesamaan (commonality)

Terdapat kesamaan fakta (peristiwa) dan kesamaan dasar hukum (question of law) antara pihak yang diwakili (class representatif) dan pihak wakili (class members). Wakil kelompok dituntut menjelaskan adanya kesamaan.

3. Sejenis (typicality)

Tuntutan (bagi plaintiff class action) maupun pembelaan (bagi defendant class action) dari seluruh anggota yang diwakili (class members) harus sejenis.

4. Wakil kelompok yang jujur (adequacy of repesentation)

Wakil kelompok harus memiliki kejujuran dan kesungguhan untuk melindungi kepentingan anggota kelompok yang diwakili.

\section{Class Action Terhadap Perusahaan Pers \\ Yang melatar belakangi terjadinya class action}

Dewasa ini, perkembangan perekonomian bangsa Indonesia tumbuh dan berkembang sangat pesat, terutama dalam sektor media cetak dan elektronik. Hal ini dapat dilihat dengan mulai bermunculanya industri-industri baru yang bergerak dalam bidang tersebut. Dengan semakin banyaknya industri-industri media cetak dan elektronik baru, maka semakin ketat pula persaingan dalam bisnis tersebut. Maka

${ }^{29}$ Sutiyoso, "Implementasi Gugatan Legal Standing dan Class Action dalam Praktik Peradilan di Indonesia," 65. 
dengan demikian sangatlah berpotensi untuk menimbulkan kerugian yang bersifat massal.

Hal tersebut dapat terjadi secara otomatis. Dengan semakin banyaknya industri-industri media cetak dan elektronik baru, maka membuat semakin ketat pula persaingan untuk mendapatkan market pasar dalam bisnis tersebut. Dengan demikian tak jarang industri tersebut megunakan sterategi dengan mengunakan sensasi dangkal untuk mendapatkan market pasar. Tanpa disadari atau tidak bahwa industri media tersebut sudah melakukan pengabaian, sehingga secara otomatis mengarah kepada suatu pelanggaran. Diantara bentuk-bentuk pengabaian itu adalah:

1. Pengabaian kaidah hukum (Iqnorantia juris).

2. Pengabaian fungsi (Iqnorantia function).

3. Pengabaian keseimbangan informasi (Iqnorantia infom).

4. Pengabaian wawasan kebangsaan (Iqnoranti nation).

Semakin ketatnya persaingan bisnis dalam media tersebut yang dikarenakan semakin banyaknya industriindustri media cetak dan elektronik baru menimbulkan bisnis yang tidak sehat dengan cara menyajikan artikel-artikel yang hanya menonjolkan segi sensasi dangkal yang mana meliputi harta, tahta dan wanita. ${ }^{30} \mathrm{Hal}$ tersebut justru dapat membawa pengaruh negatif dalam kehidupan sosial masyarakat, mengingat media memiliki peranan penting dalam kehidupan masyarakat, karena media memiliki fungsi sebagai media yang mendidik, menghibur, dan mempengaruhi.

Guna menangani masalah pelanggaran hukum yang mengakibatkan kerugian yang bersifat massal, maka Mahkama Agung Republik Indonesia menetapkan PERMA Nomor 1 Tahun 2002 tentang gugatan perwakilan kelompok: "Bahwa untuk kepentingan efisiensi dan efektifitas berperkara, pelanggaran hukum, maka dapat mengajukan gugatan perwakilan kelompok, dalam mana satu orang atau lebih pihak yang dirugikan atas pelanggaran hukum tersebut, mengajukan gugatan untuk diri atau diri-diri mereka sendiri dan sekaligus

30 Bungin, Erotika Media Massa, 2. 
mewakili orang yang jumlahnya banyak, yang memiliki fakta, dasar hukum, dan tergugat yang sama."

Dengan demikian untuk mengatasi permasalahan pelanggaran hukum yang mana mengakibatkan kerugian yang bersifat massal, maka perlu adanya class action. Dan di dalam class action itu sendiri memiliki 3 (tiga) dasar hukum, di antaranya:

1. Undang-undang pengelolaan lingkungan.

2. Undang-undang kehutanan.

3. Undang-undang perlindungan konsumen.

Yang digunakan sebagai dasar hukum dalam pengajukan class action terhadap industri-industri media cetak dan elektronik yang mengakibatkan kerugian yang bersifat massal adalah hukum perlindungan konsumen. Disebutkan dalam pasal 46, UU No.8 Tahun 1999 bahwa: "Gugatan atas pelanggaran pelaku usaha dapat dilakukan sekelompok konsumen yang memiliki kepentingan yang sama."

Di dalam UUPK norma-norma dikelompokan menjadi dua kelompok. Yaitu:31 pertama, perbuatan yang dilarang bagi pelaku usaha yang terdapat didalam UUPK pasal 8-17. yang mana dalam hal ini, kerugian yang dialami oleh konsumen disebabkan oleh produk yang tidak sesuai dengan standar ketentuan/peraturan perundang-undangan, produk cacat meskipun masih dalam garansi atau belum kadaluwarsa, ketidak sesuian iklan, informasi produk dengan kenyataan, tingkat keamanan produk diinformasikan tidak secara proposional.

Kedua, ketentuan pencantuman klausula baku terdapat didalam UUPK pasal 18. yang didalamnya menyebutkan tentang pelanggaran oleh pelaku usaha. Yang mana para pelaku usaha dilarang untuk mencantumkan informasi yang menyatakan konsumen dilarang mengembalikan barang yang sudah dibeli, mengalihkan tanggung jawab kepada pihak lain, mencantumkan klausula

31 UUPK Nomor 8 Tahun 1999, pasal 8 ayat (1), (2) dan (3), pasal 9 ayat (1), (2) dan (3), pasal 10, pasal 11, pasal 13 ayat (1) dan (2), pasal 14, pasal 15, pasal 16, pasal 17 ayat (1) dan (2), serta pasal 18 ayat (1), (2) dan (4). 
baku yang bentuknya sulit atau tidak dapat dibaca secara jelas.

Jadi dengan adanya aturan hukum yang mengatur tentang class action, bukan berarti mempunyai maksud dan tujuan untuk mematikan bisnis para pelaku usaha, atau bahkan justu sebaliknya. Dengan diterapkannya aturan yang mengatur tentang class action justru dapat menumbuhkan iklim bisnis yang sehat. Di samping juga dapat memunculkan industri-industri yang tangguh dalam menghadapi persaingan bisnis dengan menyediakan barang dan/ atau jasa yang berkualitas, dan bukan hanya mementingkan segi komersil saja.

\section{Kreteria Pelanggaran Perusahaan Pers Dalam Kontek Indonesia}

Sebagaimana yang telah disebutkan atau telah di jelaskan sebelumya bahwasannya pers memiliki fungsi sebagai media penyiar informasi, mendidik, menghibur, dan mempengaruhi. Dengan demikian pers memiliki suatu peranan yang sangat penting untuk kemajuan Negara. Sebab pers merupakan salah kebutuhan manusia yang sangat esensial untuk berbagai tujuan. Di samping itu pers merupakan media produk yang memiliki sifat universal dan aktual.

Dengan lengsernya massa Permerintahan Soeharto, atau yang lebih dikenal dengan rezim orde baru, maka euforia kebebasan telah didapatkan kembali oleh insan pers. Hal ini juga dapat dirasakan dengan suburnya minat masyarakat untuk bergelut dalam bisnis tersebut. ${ }^{2}$

Kebebasan pers merupakan salah satu cirikhas dari Negara yang menganut asas demokrasi, yang ditandai dengan adanya hak setiap warga Negara untuk bebas berekspresi, serta memperoleh dan menyebarkan informasi. Hal tersebut tumbuh dan berkembang seiring dengan demokrasi. Karena demokrasi itu sendiri didasarkan pada kesepakatan dan

32 Idri, "Pers dalam Wacana Hukum (Kajian tentang Kebebasan, Tanggungjawab, dan Deviasi Pers dalam Perspektif Hukum Islam dan Hukum Positif di Indonesia)," 233. 
keikut sertaan. Untuk itu kebebasan berekspresi dan berkomunikasi merupakan syarat yang penting bagi tegaknya demokrasi.

Dengan semakin menjamurnya industri-industri media cetak dan elektronik, membuat semakin ketat pula persaingan merebutkan market pasar dalam bisnis tersebut. Dampaknya tak jarang perusahaan media tersebut dalam berebut memperoleh market pasar menggunakan setrategi penyajian berita atau artikel yang mengunakan segi sensasisensasi dangkal saja, tanpa memikirkan bobot dari berita yang disajikan. Sensasi dangkal tersebut meliputi harta, tahta dan wanita. 33

Hal ini tidak dapat dipungkiri. Dengan menggunakan segi sensasi dangkal, perusahan media tersebut dapat membuka peluang besar untuk mendapatkan market pasar, yang antara lain: pertama untuk memudahkan dan mempercepat dalam meraup keuntungan. Kedua, keuntungan yang didapat lebih besar jika dibandingkan dengan modalnya. Ketiga, segi sensasi dangkal tersebut sangat diminati oleh konsumen dan mampu menarik konsumen dengan mudah. Keempat, memudahkan dalam hal pemasaran.

Dalam pasal-pasal KUHP (Kitab Undang-undang Hukum Pidana) telah membatasi atau memberi rambu-rambu terhadap kebebasan pers dalam pemberitaannya, yang mana meliputi melarang menyebarkan berita atau artikel yang sifatnya menghina baik terhadap Negara/pemerintah maupun terhadap nama baik seseorang. Di samping itu kebebasan pers dibatasi dengan larangan menyebarkan tulisan atau gambar yang tergolong pornografi, menodai agama atau memprovokasi masyarakat untuk melakukan tindak pidana tertentu. ${ }^{34}$

Dan secara khusus batas-batas dari kebebasan perusahaan pers telah dijelaskan dalam pasal 13 Undangundang Nomor 40 Tahun 1999 tentang Kebebasan Pers: "Bahwa perusahaan pers dilarang untuk menyajikan artikel

33 Bungin, Erotika Media Massa, 2.

34 Murani, “Aspek Hukum dan Tanggung Jawab Pers," 30. 
yang berakibat merendahkan martabat suatu agama dan atau menganggu kerukunan hidup antar umat beragama, serta bertentangan dengan rasa kesusilaan masyarakat." 35

Kebebasan pers merupakan suatu wujud dari kedaulatan rakyat, dan juga memilki peranan yang sangat penting di era reformasi ini. Namun di balik kebebasannya itu, maka pers juga memiliki batas-batasnya.

\section{Analisis Hukum Pidana Islam Tentang Class Action Terhadap Perushaan Pers}

Agam Islam merupakan agama yang sempurna. Agama yang dibawa oleh Nabi Muhammad SAW ini memiliki misi untuk memberikan petunjuk bagi seluruh umat manusia yang ada dibumi. ${ }^{36}$ Dan yang dijadikan sebagai dasar hukum dasar hukum untuk menetapkan sanksi atau hukuman dalam agama Islam adalah al-Qur'an dan hadis. Secara global dalam al-Qur'an telah menetapkan aturan-aturan yang bersifat yuridis maupun etis. Baik yang bersifat yuridis maupun etis dalam penataan dan pelaksanaannya memiliki maksud dan tujuan untuk membentuk masyarakat Islam yang baik dan damai.

Akan tetapi ada beberapa pelanggaran yang secara langsung tidak ditetapkan atau tidak ada nașs-nya di dalam alQur'an dan hadis. Maka dalam menetapkan sanksi atau hukumannya diserahkan kepada kebijakan ulil amri sesuai dengan kondisi pada saat itu, seperti dalam kasus ta'zir. Hal ini memiliki maksud dan tujuan untuk mengatasi permasalahan-permasalahan yang akan timbul seiring dengan perkembangan zaman. Dalam sistem hukum pidana Islam berlaku filosofi bahwa mencegah lebih baik daripada mengobati, di samping juga sistem pidana yang ketat dan

35 Idri, "Pers dalam Wacana Hukum (Kajian tentang Kebebasan, Tanggungjawab, dan Deviasi Pers dalam Perspektif Hukum Islam dan Hukum Positif di Indonesia)," 229.

36 Sebagaimana firman Allah SWT. dalam surat al-Anbiyā' ayat 107, yang artinya: "Dan tidaklah kami mengutus kamu (muhammad) melainkan untuk menjadi rahmatan bagi alam semesta." Lihat: Departemen Agama RI, Al-Qur'an Dan Terjemahannya (Semarang: Tanjung Mas Inti, 1992), 331. 
efektif demi untuk mencapai perdamaian dan stabilitas masyarakat. 37

Salah satu bentuk kasus yang sanksinya harus ditentukan oleh ulil amri yang berdasarkan pada kemaslahatan umat adalah class action terhadap perusahaan pers. Dengan adanya class action merupakan salah satu bentuk untuk mengantisipasi adanya kerugian secara massal yang disebabkan oleh perusahan pers. Dalam hal ini bertujuan untuk membuat perusahan pers agar lebih berhatihati dalam menjalankan bisnisnya. Dalam sebuah kaidah menyebutkan: al-ta'zir yadur ma' al-mașlahah (ta'zir itu sangat tergantung kepada tuntutan kemaslahatan). ${ }^{38}$

Dengan demikian perusahan pers dalam menjalankan bisnisnya harus mematuhi peraturan atau rambu-rambu yang telah diatur. Disebukan dalam pasal 13 Undang-undang Nomor 40 Tahun 1999 tentang Kebebasan Pers, bahwa: "Perusahaan pers dilarang menerbitkan artikel yang berakibat merendahkan martabat suatu agama dan atau mengganggu kerukunan hidup antar umat beragama, serta bertententangan dengan kesusilaan masyarakat."

Dengan adanya pelanggaran yang telah dilakukan oleh perusahaan pers, yang sesuai dengan penjelasan yang terdapat dalam pasal 13 Undang-Undang Nomor 40 Tahun 1999 tentang Kebebasan Pers, dan mengakibatkan kerugian yang bersifat massal, maka secara otomatis dapat mengunakan class action. Hal ini sesuai dengan ketentuan yang terdapat pasal 46 Undang-undang Nomor 8 Tahun 1999 tentang Perlidungan Konsumen bahwa: "Gugatan atas pelanggaran pelaku usaha dapat dilakukan oleh sekelompok yang memiliki kepentingan yang sama."

Dengan ditetapkannya aturan yang mengatur tentang class action, membuat perusahaan pers lebih berhati-hati dalam menjalankan bisnisnya agar tidak memandang masyarakat hanya sebagai obyek pemasaran produk media.

37 Nafi' Mubarok, “Tujuan Pemidanaan dalam Hukum Pidana Nasional dan Fiqh Jinayah," Jurnal Al-Qanun 21, no. 2 (Desember 2015): 312.

38 Ahmad Djazuli, Fiqih Jinayah (Jakarta: Raja Grafindo Persada, 1996), 166. 
Hal ini sesuai dengan kaidah hukum yang telah dijelaskan tentang sanksi $t a^{\prime} z i r$ yang mana tergantung dengan kemaslahatan. Hal ini juga dikuatkan oleh pernyataan Abu Zahrah, yang menyatakan bahwa fungsi dari hukum itu sendiri, yaitu: ${ }^{39}$

1. Mendidik individu agar mampu menjadi sumber kebaikan bagi masyarakatnya dan tidak menjadi sumber malapetaka bagi yang lain, sebagaimana sabda Nabi saw. 40

2. Menegakkan keadilan dalam masyarakat secara internal di antara sesama umat Islam dengan masyarakat umum, sebagaimana firman Allah SWT dalam suart al-Māidah ayat 8.41 Keadilan merupakan prinsip dasar dalam membangun kesejahteraan masyarakat. Tanpa keadilan masyarakat sulit mendapatkan ketenteraman dalam hidup. Seseorang dipandang adil apabila mampu memberikan keputusan moderat, tidak berat sebelah terhadap orang yang mencari keadilan dan memandang semua orang sama tanpa artikulasi jabatan atau kedudukan.

3. Mewujudkan kemaslahatan yang haqiqi bagi sesama manusia. Tujuan dari hukum pidana Islam itu sendiri adalah untuk mewujudkan kemaslahatan bagi masyarakat baik di dunia maupun di akhirat, menolak kemudorotan dan mendatangkan kemaslahatan. ${ }^{42}$

Penjelasan dari tujuan ditetapkannya hukum d iatas memberikan gambaran bahwa pemberian sanksi atau

${ }^{39}$ Muhammad Abu Zahrah, Ilmu Usul Fiqh, Jilid 1 (Beirut: Dār al-Fikr, 1992), 289.

40 Disebutkan dalam hadits riwayat Imam Muslim dari Tamim Ad-Daari ra., bahwa Nabi saw. bersabda: "Agama itu adalah nasehat. Kami bertanya, "Untuk siapa?" Sabda beliau, "Untuk Allah, kitab-Nya, rasul-Nya, para pemimpin umat Islam, dan bagi seluruh umat muslim." Lihat: Muslim ibn al-Ḥajjāj, Jāmi' al-Ṣohih, Jilid 2 (Beirut: Dār al-Fikr, t.t.), 32.

41 Disebutkan dalam QS. al-Maidah ayat 8, yang artinya: "Dan janglah sekalikali kebencian terhadap suatu kaum mendorong kamu untuk berlaku tidak adil. Berlaku adillah karena adil itu lebih dekat kepada takwa kepada allah, sesungguhnya allah maha mengetahui apa yang kamu kerjakan." Departemen Agama RI, Al-Qur'an Dan Terjemahannya, 138.

42 Mubarok, "Tujuan Pemidanaan dalam Hukum Pidana Nasional dan Fiqh Jinayah," 298. 
hukuman bagi setiap para pelaku jarimah merupakan salah satu bentuk pengajaran sebagai fungsi profentif dan represif serta fungsi kuratif dan edukatif. Bentuk prefentif memberikan maksud bahwa sanksi atau hukuman yang diberikan kepada para pelaku jarimah dapat memberikan dampak positif bagi orang lain, sehingga orang lain tidak meniru atas perbuatan yang dilakukan oleh si pelaku jarimah. Represif memberikan maksud bahwa sanksi atau hukuman yang diberikan harus memiliki dampak positif bagi perilaku pribadi jarimah, sehingga ia sadar dan tidak mengulangi lagi perbuatannya. Sedangkan untuk fungsi edukatif memberikan maksud bahwa sanksi yang diberikan kepada pelaku harus dapat mengubah pola pikir agar menjauhi perbuatan jarimah. Dan fungsi kuratif memberikan maksud bahwa sanksi yang diberikan kepada pelaku harus mampu merubah sikap para pelaku jarimah dalam menjalankan hukuman di kemudian hari.

Di dalam agama Islam tetah ditetapkan nilai, etika yang harus dipatuhi dalam menjalankan kegitan bisnis yang dilakukan oleh pelaku usaha. Hal ini dapat dilihat dalam QS. al-Shur'ara ayat 183, yang artinya: "Dan jangan kamu merugikan manusia pada hak-haknya dan janganlah kamu merajarela dimuka bumi dengan membuat kerusakan."

Juga, hukum Islam melarang berbagai macam bentuk bisnis yang dijalankan dengan cara yang haram. Dengan demikian pejelasan dari kaidah fiqhiyyah di atas mengisaratkan bahwa segala sesuatu yang dapat timbul perbuatan haram, maka perbuatan itu adalah haram.

Inilah yang membedakan sistem ekonomi Islam dengan sistem ekonomi lainnya. Bahwa sistem ekonomi Islam berangkat dari kesadaran tentang etika, sebuah ethical economy. Berbeda dengan sistem ekonomi kapitalis dan sosialis dimana keduanya berangkat dari kepentingan. Kapitalisme berangkat dari kepentingan perorangan (selfishness), sedangkan sosialissme berangkat dari kepentingan kolektif (colective).43

43 Syihabuddin, "Etika Distribusi dalam Ekonomi Islam," 92.

Al-Qānūn, Vol. 22, No. 1, Juni 2019 
Jadi pelanggaran yang telah dilakukan oleh perusahan pers dan mengakibatkan kerugian yang bersifat massal, maka dapat dikenakan hukuman pidana. Bentuknya berupa pidana penjara dan pidana denda 2.000.000.000,- (dua milyar rupiah), dan dapat dijatuhkan hukuman tambahan. Ini sesuai dengan pasal 63 Undang-undang Nomor 8 Tahun 1999 tentang Perlindungan Konsumen, yaitu: "Terhadap sanksi pidana sebagaimana dimaksud dalam pasal 62, dan dapat diajukan hukuman tambahan berupa perampasan barang tertentu, pengumuman keputusan hakim, pembayaran ganti rugi, perintah pemberhentian kegiatan tertentu yang menyebabkan timbulnya kerugian konsumen, pencabutan izin usaha."

Sebagaimana yang telah dijelaskan sebelumnya bahwa dalam hukum pidana Islam mengenai hukuman atau sanksi ta'zir. Ta'zir adalah hukuman yang belum ditentukan kadar hukumnya oleh syara' yang dalam menentukan hukumannya diserahkan kepada ulil amri. Di antara sanksi ta'zír yaitu hukuman berkaitan dengan harta (penyitaan), pengumuman kesalahan secara terbuka, dan pengucilan. Hukuman ini dapat diberikan kepada perusahan pers yang melanggar ketentuan undang-undang pers (pasal 13 UU No. 40 Tahun 1999 tentang Kebebasan Pers). Dan dalam menjalankan bisnisnya perusahaan pers menyebabkan kerugian yang bersifat massal, dapat mengunakan class action dengan mengunakan dasar hukum perlindungan konsumen (pasal 46, UU No. 8 Tahun 1999 tentang Perlindungan Konsumen). Selain hukuman pidana penjara dan pidana denda, juga dapat dikenakan hukuman tambahan yang terdapat pada penjelasan pasal 63 Undang-Undang Nomor 8 Tahun 1999 tentang Perlidungan Konsumen. Yang mana sanksi pidananya berupa: (1) perampasan barang tertentu, (2) pengumuman keputusan hakim, (3) pembayaran ganti rugi, (4) perintah pemberhentian kegiatan yang menimbulkan kerugian konsumen, (5) kewajiban penarikan barang dari peredaran, dan/atau (6) pencabutan izin usaha. Hal ini sesuai dengan maksud dan tujuan hukum itu sendiri yaitu untuk mendidik pelaku demi kemaslahatan umat. 


\section{Penutup}

Berdasarkan berbagai pemaparan sebelumnya, maka bisa ditarik kesimpulan sebagai berikut:

1. Class action terhadap perusahaan pers dapat dilakukan apabila perusahaan pers dalam menjalankan bisnisnya bertindak tidak sesuai dengan peraturan undang-undang pers yang belaku (Pasal 13 UU No. 40 Tahun 1999 tentang Kebebasan Pers), dan apabila perushaan pers dalam menjalankan bisnisnya perusahaan pers menyebabkan kerugian secara massal. Dalam hal ini dapat mengunakan class action dengan dasar pasal 46 Undang-undang Nomor 8 Tahun 1999 tentang Perlindungan Konsumen.

2. Sanksi atau hukuman dalam hukum pidana Islam termasuk dalam katagori ta'zir yang meliputi perampasan barang tertentu (penyitaan), pengumuman kesalahan secara terbuka, dan pengucilan. Hal ini sesuai dengan sanksi pidana yang terdapat pada undang-undang perlindungan konsumen yakni dapat dikenakan hukuman tambaham selain hukuman pidana penjara dan pidana denda yang terdapat pada penjelasan pasal 63 Undang-undang Nomor 8 Tahun 1999 tentang Perlidungan Konsumen. Sanksi pidana berupa: (1) perampasan barang terentu, (2) pengumuman keputusan hakim, (3) pembayaran ganti rugi, (4) perintah pemberhentian kegiatan tertentu yang menyebabkan timbulnya kerugian konsumen, (5) kewajiban penarikan barang diperedaran, dan/atau (6) pencabutan izin usaha. Maksud dan tujuan dari pemberian pidana, menurut hukum positif dan hukum pidana Islam, tak lain adalah untuk untuk menjaga ketertiban umum dan mendidik pelaku demi kemaslahatan umat.

\section{Daftar Pustaka}

Bungin, Burhan. Erotika Media Massa. Surakarta: Universitas Muhamadiyah Surakarta, 2001.

Departemen Agama RI. Al-Qur'an Dan Terjemahannya. Semarang:

Tanjung Mas Inti, 1992. 
Djazuli, Ahmad. Fiqih Jinayah. Jakarta: Raja Grafindo Persada, 1996. Effendy, Onong Uchjana. Ilmu, Teori dan Filsafat Komunikasi. Bandung: Citra Aditya Bakti, 2003.

Ḥajjāj, Muslim ibn al-. Jämi' al-Sohih. Jilid 2. Beirut: Dār al-Fikr, t.t. Idri. "Pers dalam Wacana Hukum (Kajian tentang Kebebasan, Tanggungjawab, dan Deviasi Pers dalam Perspektif Hukum Islam dan Hukum Positif di Indonesia)." Al-Ihkam V, no. 2 (Desember 2010).

Mahdi, Acan. "Kebebasan Pers dan Hak Publik." Al-Hikmah 8, no. 1 (2014).

Mahfud MD, Moh. Hukum dan Pilar-pilar Demokrasi. Yogyakarta: Gama Media, 1999.

Mappong, Kadir. "Prosedur Gugatan Perwakilan (Class Action) dan Kaitannya dengan Hukum Acara Perdata." Seminar Sehari, Oktober 2002.

Mubarok, Nafi'. Kriminologi dalam Prespektif Islam. Sidoarjo: Dwiputra Pustaka Jaya, 2017.

- - . "Tujuan Pemidanaan dalam Hukum Pidana Nasional dan Fiqh Jinayah." Jurnal Al-Qanun 21, no. 2 (Desember 2015).

Murani, Asnawi. "Aspek Hukum dan Tanggung Jawab Pers." Jurnal Ilmu Komunikasi 1, no. 2 (Desember 2015).

Santoso, Ahmad. Konsep dan Penerapan Gugatan Perwakilan Class Action. Jakarta: ICEL, 1997.

Sugeng A.S, Bambang. "Penyelesaian Sengketa Konsumen Melalui Gugatan Kelompok." Yuridika 25, no. 2 (Mei-Agustus 2010).

Sutiyoso, Bambang. "Implementasi Gugatan Legal Standing dan Class Action dalam Praktik Peradilan di Indonesia." Jurnal Hukum 26, no. 11 (Mei 2004).

Syihabuddin, Atok. "Etika Distribusi dalam Ekonomi Islam." Jurnal Al-Q̄̄̄ün 20, no. 1 (Juni 2017).

Yazid, Muhammad. "Prospek Ekonomi Syariah dalam Menjawab Tantangan Keadilan Sosial dan Kapitalisme Global." Jurnal Al-Qānün 12, no. 1 (Juni 2009).

Yuntho, Emerson. Class Action: Sebuah Pengantar. Jakarta: ELSAM, 2007.

Zahrah, Muhammad Abu. Ilmu Usul Fiqh. Jilid 1. Beirut: Dār al-Fikr, 1992. 